\title{
KEEFEKTIFAN HUMAN CAPITAL INVESTMENT PENDIDIKAN TENAGA KEPENDIDIKAN DI UNIVERSITAS NEGERI YOGYAKARTA
}

\author{
Fitri Nur Mahmudah, Lantip Diat Prasojo \\ Fakultas Ekonomi UNY, Fakultas Ilmu Pendidikan UNY \\ fnurmahmudah@gmail.com, lantip1975@gmail.com
}

\begin{abstract}
Abstrak
Penelitian ini bertujuan untuk menganalisis: (1) payback period (PP), (2) benefit/cost ratio, (3) return on investment (ROI), (4) net present value (NPV), dan (5) internal rate of return (IRR) dalam perspektif pendidikan bagi tenaga kependidikan di Universitas Negeri Yogyakarta. Penelitian ini adalah Evaluasi dengan model Discrepancy. Instrumen pengumpulan berupa angket yang ditujukan kepada tenaga kependidikan di UNY dengan skala Guttman. Validitas instrumen meliputi validitas logis dan validitas empiris yang dihitung dengan Pearson product moment. Reliabilitasnya dihitung dengan teknik Kuder Richardson (KR20). Teknik analisis data dengan menggunakan deskriptif dan persentase. Hasil penelitian menunjukkan bahwa: (1) payback period investasi dalam bentuk pendidikan bagi tenaga kependidikan yang melakukan peningkatan kualifikasi pendidikan tidak melebihi batas waktu yang ditentukan, sehingga invetasi dalam bentuk pendidikan efektif (feasible); (2) benefit/cost ratio investasi dalam pendidikan memberikan manfaat positif bagi tenaga kependidikan; (3) return on investment dalam perspektif pendidikan bagi tenaga kependidikan memiliki nilai positif sehingga investasi dapat dipertimbangkan; (4) net present value yang diperoleh bernilai positif sehingga investasi dalam perspektif pendidikan bagi tenaga kependidikan di Unviersitas Negeri Yogyakarta dapat dikatakan feasible.

Kata kunci: human capital investment, payback period, benefit/cost ratio, return on investment, net present value, internal rate of return
\end{abstract}

\section{AN EFFECTIVENESS OF HUMAN CAPITAL INVESTMENT IN EDUCATION FOR EDUCATOR PERSONNEL AT YOGYAKARTA STATE UNIVERSITY}

\author{
Fitri Nur Mahmudah, Lantip Diat Prasojo \\ Fakultas Ekonomi UNY, Fakultas Ilmu Pendidikan UNY \\ fnurmahmudah@gmail.com, lantip1975@gmail.com
}

\begin{abstract}
This study aims to analyze (1) payback period (PP), (2) benefit / cost ratio, (3) return on investment (ROI), (4) net present value (NPV), and 5) internal rate of return (IRR) in the perspective of education for education personnel at Yogyakarta State University. This study is an evaluation using the discrepancy model. The instrument for collecting data was in the form of questionnaires addressed to education personnel in YSU with Guttman scale. The validity of the instrument included logical validity and empirical validity and was calculated by using the Pearson product moment. The reliability was measured by using Kuder Richardson (KR20) technique. The data were analyzed using descriptive and percentage techniques. The results show that: (1) the period of time of return on investment in the form of education for education personnel who improved their education qualification did not exceed the time limit, so investment in the form of education is feasible; (2) the benefit/cost ratio of investment in education provides positive; (3) the return on investment in education perspective for education personnel has a positive; (4) the obtained net present value is positive, so it can be said that investment in education perspective for education personnel in Yogyakarta State University is feasible; (5) the internal rate of return is greater than the cost of capital so investing in education perspective is feasible.
\end{abstract}

Keywords: human capital investment, payback period, benefit/cost ratio, return on investment, net present value, internal rate of return 


\section{Pendahuluan}

Memasuki abad 21, bangsa Indonesia makin sadar akan pentingnya meningkatkan sumber daya manusia (SDM) yang cerdas, jujur, terampil, dan professional dalam ilmu pengetahuan dan manajemen. Keberhasilan pembangunan nasional ditentukan oleh kualitas sumber daya manusia. Pembangunan modal sosial dapat berarti terciptanya insan yang sempurna. Era globalisasi menjadi tantangan sendiri untuk lembaga pendidikan, di samping harus menciptakan SDM yang mampu berkompetensi dan berprestasi, juga harus dapat menyiapkannya agar mampu menghadapi akulturasi budaya yang luar biasa.

Pada era global pendidikan di Indonesia dituntut mempunyai peran ganda, yaitu harus mempersiapkan manusia yang berkualitas dan mampu berkompetisi sesuai dengan kemajuan ilmu dan teknologi, atau manusia yang mempunyai kesiapan mental dan sekaligus kesiapan kemampuan skill (professional) dan dunia pendidikan ini mampu menyiapkan manusia yang berkompeten.

Indonesia masih menempati peringkat 121 dari 187 negara yang di komparasikan oleh lembaga dibawah PBB United Nations Development Programme (UNDP). Dari tiga dimensi yang diukur oleh UNDP kualitas bobot dimensi pembangunan manusia yang tertinggi adalah kesehatan $(0,785)$ dikuti oleh pendidikan $(0,577)$ dan ekonomi $(0,550)$ dengan total HDI adalah 0,629 seperti yang disajikan pada Gambar 1.

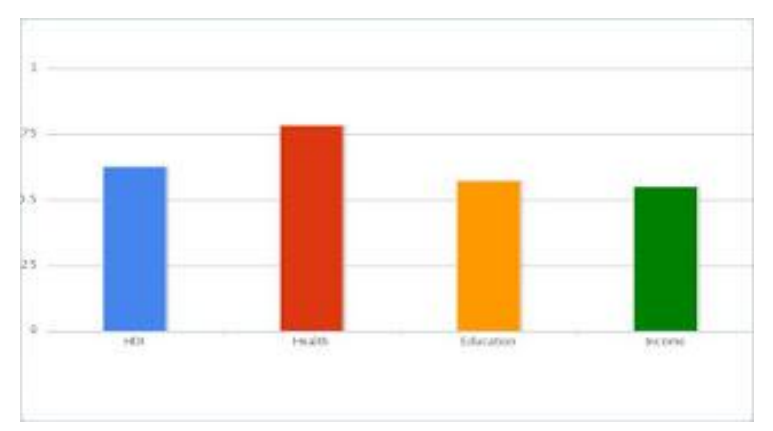

Gambar 1. Grafik HDI Indonesia 2012

Angka ini mengalami peningkatan dari tahun ke tahun walaupun masih berada dibawah rata-rata negara-negara Asia
Timur dan Pasifik $(0,683)$. Tren kenaikan HDI Indonesia dapat dilihat pada grafik yang disajikan pada Gambar 2.

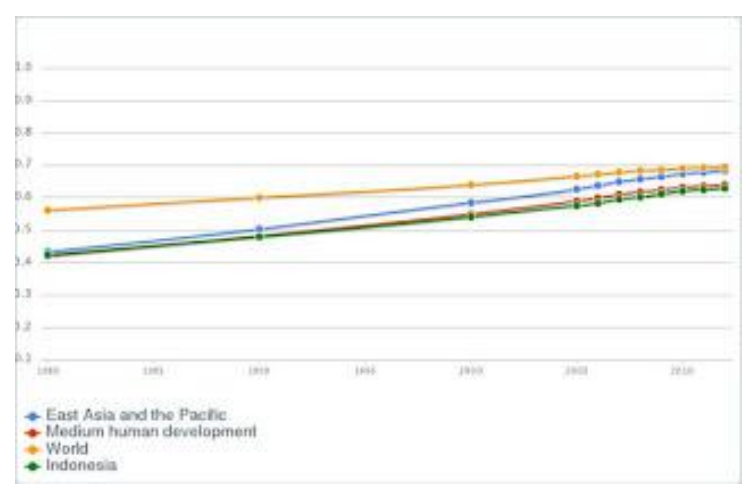

Gambar 2. Grafik Tren HDI Indonesia Tahun 1980-2012

Di tingkat ASEAN, Indonesia masih di posisi 121 dari 185 negara dalam Indeks Pembangunan Manusia (IPM) dengan angka 0,629. Angkat tersebut Indonesia tertinggal dari dua negara tetangga ASEAN yaitu Malaysia (peringkat 64) dan Singapura (18), sedangkan IPM di kawasan Asia Pasifik adalah 0,683. Pada ranah kualitas dari pendidikan yang diberikan tersebut. Mencakup kurikulum, tenaga pendidik, infrastruktur pendidikan, dan lain-lain.

Produktivitas tenaga kerja di Indonesia. Pekerja Indonesia dibandingkan dengan pekerja Amerika Serikat hanya mencapai $36 \%$. Artinya, jam kerja yang dihabiskan pekerja Indonesia hanya $36 \%$ di atas pekerja Amerika. Sementara pekerja Kamboja mencapai 46\%, Malaysia mencapai $43 \%$, Thailand $37 \%$ dan Singapura $36 \%$. Pekerja Indonesia hanya lebih produktif dibandingkan Filipian 30\% dan Vietnam $13 \%$.

Asian Productivity Organization (APO) mencatat, dari setiap 1.000 tenaga kerja Indonesia pada tahun 2012, hanya ada sekitar 4,3\% tenaga kerja yang terampil. Jumlah itu kalah jauh dibandingkan dengan Filipina yang mencapai 8,3\%, Malaysia 32,6\%, dan Singapura 34,7\% . Dalam indeks daya saing global yang menunjukan produktivitas dari mulai sumberdaya alam hingga sumber daya manusia pun Indonesia masih jauh tertinggal dari negaranegara ASEAN lainnya. Indonesia berada di urutan ke-5 di ASEAN (50 dunia) pada 
laporan Global Competitivenes Index 20112012 yang dikeluarkan oleh World Economic Forum seperti disajikan pada Tabel 1.

Tabel 1. Peringkat Global Competitiveness Index Beberapa Negara

\begin{tabular}{llccc}
\hline No Negara & 2008 & 2012 & Perubahan \\
\hline 1 & Singapura & 5 & 2 & 3 \\
2 & Malaysia & 21 & 25 & -4 \\
3 & Brunei Darussalam & 39 & 28 & 11 \\
4 & Thailand & 34 & 38 & -4 \\
5 & Indonesia & 55 & 50 & 5 \\
6 & Filipina & 71 & 65 & 6 \\
7 & Vienam & 70 & 75 & -5 \\
8 & Kambodia & 109 & 85 & 24 \\
9 & Timor-Leste & 129 & 136 & -7 \\
\hline
\end{tabular}

Sumber daya manusia (SDM) yang handal merupakan pondasi yang kuat dalam menghadapi perubahan jaman dan pencapaian kinerja yang prima pada suatu organisasi. Tenaga kependidikan menjadi unsur penting yang mempunyai fungsi besar dan hal itu merupakan fakta yang tidak dapat terelakkan. Tenaga kependidikan merupakan faktor produksi yang bersifat senantiasa bergerak dan selalu berubahubah, mempunyai akal dan perasaan serta motivasi, jika tenaga kependidikan sebagai faktor produksi merasa senang bekerja dengan penuh semangat dan bergairah, maka dapat dipastikan bahwa tujuan yang telah ditetapkan organisasi akan semakin mudah tercapai.

Peningkatan kualitas sumber daya manusia (SDM) menjadi perhatian semua pihak dalam memasuki era globalisasi ini. Terlebih dalam suasana krisis multidimensi, masyarakat membutuhkan dukungan berbagai pihak untuk menghadapi persaingan bebas. Untuk itu pendidikan memegang peranan penting bagi peningkatan kualitas sumberdaya yang dimiliki. Peningkatan pendidikan menjadi salah satu sarana untuk meningkatkan potensi dasar yang dimiliki oleh pegawai. Indikator kualitas sumber daya manusia (SDM) dapat berupa tingkat pendidikan.

Menteri Pendayagunaan Aparatur Negara dan Reformasi Birokrasi, mengatakan bahwa dari 4,7 juta Pegawai Negeri
Sipil (PNS), sebanyak 95\% PNS tidak kompeten, dan hanya $5 \%$ memiliki kompetensi dalam pekerjaannya (Harian Umum Pikiran Rakyat, Kamis 1 Maret 2012).

Pernyataan Menteri Pendayagunaan Aparatur Negara dan Reformasi Birokrasi tersebut mungkin mendapat tanggapan yang beragam dari berbagai kalangan, baik kalangan PNS itu sendiri maupun yang bekerja di sektor swasta. Bagi kalangan PNS merupakan salah satu bahan introspeksi diri untuk memperbaiki dan meningkatkan kompetensi, karena PNS adalah berkedudukan sebagai unsur aparatur negara yang bertugas untuk memberikan pelayanan secara umum kepada masyarakat secara profesional, jujur, adil, dan merata dalam penyelenggaraan tugas negara, pemerintahan, dan pembangunan.

Undang-undang Nomor 8 Tahun 1974 dan Undang-undang Nomor 43 Tahun 1999 tentang Pokok-pokok Kepegawaian, dijelaskan bahwa Pegawai Negeri adalah setiap warga negara Republik Indonesia yang telah memenuhi syarat yang ditentukan, diangkat oleh pejabat yang berwenang dan diserahi tugas dalam suatu jabatan negeri, atau diserahi tugas negara lainnya, dan digaji berdasarkan peraturan perundang-undangan yang berlaku. Selanjutnya dijelaskan bahwa Pegawai Negeri terdiri dari: Pegawai Negeri Sipil, Anggota Tentara Nasional Indonesia; dan Anggota Kepolisian Negara Republik Indonesia.

Pegawai Negeri Sipil (PNS) terdiri dari: Pegawai Negeri Sipil Pusat dan Pegawai Negeri Sipil Daerah. Dapat dibayangkan jika seandainya PNS ini tidak memiliki kompetensi, akan berakibat atau berpengaruh terhadap pelayanan kepada masyarakat, misalnya pelayanan menjadi lambat, bekerja asal-asalan, tidak maksimal, tidak efisien dan hasilnya tidak sesuai dengan standar operasional prosedur (SOP) yang telah ditentukan.

Permasalahan mendasar kualitas sumber daya manusia (SDM) yang dihadapi banyak organisasi salah satunya adalah organisasi yang berada di bawah naungan pemerintah yaitu Universitas Negeri Yogyakarta, mengubah sistem reward dari 
pay for position menjadi pay for person. Sistem penggajian pun berubah, jika sebelumnya porsi basic salary (gaji pokok) lebih besar daripada variable salary (insentif atau bonus), kini semakin memperbesar porsi variable salary, itu berarti setiap orang dinilai berdasarkan kinerjanya (pay for performance).

Pegawai Negeri Sipil yang ada di Universitas Negeri Yogyakarta dalam hal ini tenaga kependidikan tidak tanggungtanggung jumlahnya dan beragam tingkat pendidikan yang telah dicapai maupun yang sedang melanjutkan pendidikan pada jenjang yang lebih tinggi. Tenaga kependidikan sebagai salah satu faktor produksi selain sumber daya alam, modal, entrepreneur untuk menghasilkan output. Semakin tinggi kualitas tenaga kependidikan, maka semakin meningkat pula efisiensi dan produktivitas suatu organisasi. Sejarah mencatat bahwa organisasi yang menerapkan paradigma pembangunan berdimensi manusia telah mampu berkembang meskipun tidak memiliki kekayaan sumber daya fisik yang berlimpah. Penekanan pada investasi manusia diyakini merupakan basis dalam meningkatkan produktivitas. Tanah, tenaga kerja, modal fisik dapat mengalami $d i-$ minishing return, sedangkan ilmu pengetahuan tidak.

Tenaga kependidikan di perguruan tinggi terdiri dari tenaga administrasi, teknisi, laboran, pranata humas, dan pustakawan. Jumlah tenaga administrasi sampai dengan Desember 2014 adalah sebanyak 968 orang, terdiri dari 536 orang PNS, 432 orang tenaga kontrak. Saat ini UNY memiliki 536 tenaga administratif yang berstatus PNS, 536 orang tersebut berpendidikan S2 sebanyak 23 orang $(4,29 \%)$, berpendidikan S1 sebanyak 195 orang $(35,28 \%)$, kependidikan D4 sebanyak 1 orang $(0,19 \%)$, D3 sebanyak 30 orang $(5,60 \%)$, D2 sebanyak 9 orang $(1,68 \%), \quad$ D1 sebanyak 1 orang $(0,19 \%)$, Sarjana Muda sebanyak 2 orang $(0,37 \%)$, berpendidikan SLTA sebanyak 239 orang $(44,59 \%)$, berpendidikan SLTP sebanyak 17 orang $(3,17 \%)$, dan berpendidikan SD sebanyak 19 orang (3,54\%) sebagaimana grafik pada Gambar 3.

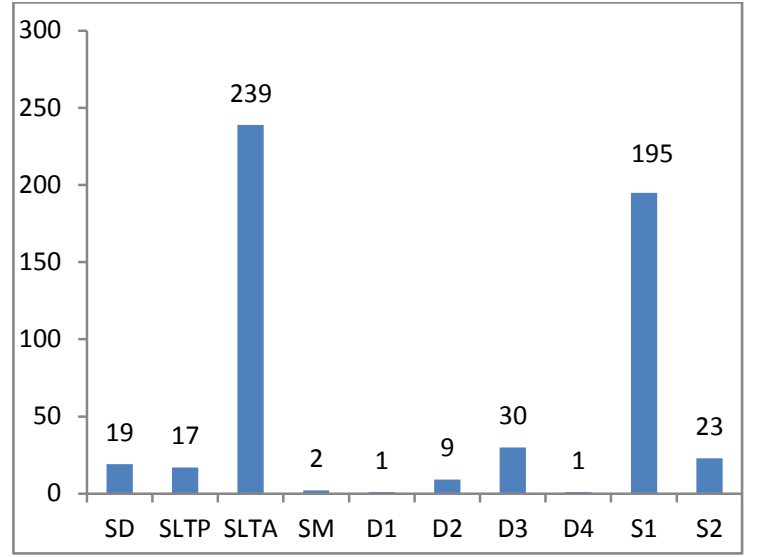

Sumber: Renstra Universitas Negeri Yogyakarta

\section{Gambar 3. Grafik Jumlah PNS menurut Pendidikan tahun 2014}

Perlunya investasi sumber daya manusia sebagai penanaman uang di Universitas Negeri Yogyakarta bertujuan membeli suatu aset yang diharapakan di masa mendatang dapat dijual kembali dengan nilai yang lebih tinggi. Investasi juga dapat dikatakan sebagai suatu penundaan konsumsi tenaga kependidikan saat ini untuk konsumsi masa depan. Harapan pada keuntungan di masa datang.

Investasi bagi tenaga kependidikan di Universitas Negeri Yogyakarta dapat dilakukan pada bidang non fisik seperti pendidikan, pelatihan, migrasi, pemeliharaan kesehatan dan lapangan kerja. Investasi non-fisik atau lebih dikenal dengan istilah investasi sumber daya manusia adalah sejumlah dana yang dikeluarkan dan kesempatan memperoleh penghasilan selama proses investasi. Investasi ini berperan dalam memacu pertumbuhan ekonomi. Investasi modal manusia melalui pendidikan di Negara berkembang sangat diperlukan walaupun investasi di bidang pendidikan merupakan investasi jangka panjang.

Faktor yang dapat menyebabkan perlunya mengembangkan tingkat pendidikan di Universitas Negeri Yogyakarta yaitu pendidikan yang lebih tinggi, memperluas pengetahuan masyarakat, dan mempertinggi rasionalitas pemikiran tenaga kependidikan. Hal ini memungkinkan tenaga kependidikan mengambil langkah yang lebih rasional dalam bertindak atau mengambil keputusan. Pendidikan memungkin- 
kan tenaga kependidikan mempelajari pengetahuan-pengetahuan teknis yang diperlukan untuk memimpin dan menjalankan manajemen modern dan kegiatan-kegiatan modern lainnya. Pengetahuan yang lebih baik yang diperoleh dari pendidikan menjadi perangsang untuk menciptakan pembaharuan-pembaharuan dalam bidang teknik, ekonomi, dan dalam berbagai aspek kehidupan masyarakat lainnya.

Bertambahnya pengalaman seorang tenaga kependidikan dalam dunia kerja, maka akan bertambah pula pengetahuan, keterampilan, kecakapan dan kecekatan dalam pengabdian kerjanya di lembaga organisasi. Semakin banyak pengalaman kerja seseorang atau semakin lamanya waktu orang tersebut untuk masa bekerja akan dapat meningkatkan kemampuan kerja sama atau dengan kata lain akan mempengaruhi peningkatan kinerja orang yang bersangkutan tersebut.

Pengalaman memang penting, namun akan lebih optimal jika diimbangi dengan tingkat pengetahuan yang terus diperbarui. Ilmu pengetahuan terus menerus berkembang, sama halnya dengan zaman. Permasalahan baru, alat dan prosedur baru, serta pekerjaan baru selalu menciptakan kebutuhan baru bagi organisasi. Sebuah organisasi jika tidak ingin tertinggal juga harus mengikuti perkembangan zaman. Kenyataan tersebut tidak dapat dipungkiri keberadaannya.

Bilamana organisasi menginginkan untuk membentuk seorang tenaga kependidikan agar organisasi semakin mengikuti perkembangan zaman, maka yang dibutuhkan adalah tingkat pendidikan seorang tenaga kependidikan yang dibutuhkan oleh organisasi. Dalam pendidikan terdapat proses yang terus menerus berjalan dan bukan sesaat saja. Namun pendidikan juga bisa disebut sebagai usaha untuk meningkatkan pengetahuan umum seseorang termasuk di dalamnya penguasaan teori untuk memutuskan persoalan-persoalan yang menyangkut kegiatan pencapaian tujuan organisasi.

Tenaga kependidikan di dalam suatu organisasi memanglah sangat penting, apa- lagi menyangkut proses inovasi. Pencapaian akhir dari pendidikan selain meningkatkan kinerja tenaga kependidikan itu sendiri juga dapat meningkatkan individual capability, individual motivation, leadership, the organizational climate, dan workgroup effectiveness (Mayo, 2000, pp. 521-533). Komponen-komponen tersebutlah yang menjadi tujuan utama dari memperlakukan sebaik-baiknya tenaga kependidikan dalam organisasi khususnya di Universitas Negeri Yogyakarta.

Banyak diantara tenaga kependidikan di UNY tersebut memiliki masa bekerja yang sudah sedemikian lama, umumnya di atas lima belas tahun mereka bertahan. Ironisnya pegawai yang senior tersebut hanya memiliki tingkat pendidikan SMP dan SMA. Jikalau hal ini tetap dipertahankan maka tak pelak, mereka akan memiliki kompetitor-kompetitor dari berbagai sub bidang ilmu yang akan membuat mereka tertinggal jauh dibelakang. Seperti yang telah diketahui bersama, dari waktu ke waktu zaman semakin berubah, pun juga yang mengikutinya seperti halnya tuntutan kerja.

Investasi pendidikan memberikan nilai balik (rate of return) yang lebih tinggi dari pada investasi fisik di bidang lain. Nilai balik pendidikan adalah perbandingan antara total biaya yang dikeluarkan untuk membiayai pendidikan dengan total pendapatan yang akan diperoleh setelah seseorang lulus dan memasuki dunia kerja.

Konsep tentang investasi sumber daya manusia (human capital investment) yang menunjang pertumbuhan ekonomi (economic growth), telah ada sejak jaman Smith (1776), Thunen (1875) dan para teoritis klasik lainnya sebelum abad ke-19 yang menekankan pentingnya human capital investment. Human capital merupakan stok dari kemampuan dan pengetahuan produktif yang terjadi pada masyarakat (Becker, 1975, pp. 334). Human capital merupakan investasi jangka panjang pada pengembangan sumberdaya manusia untuk meningkatkan produktivitas. Pentingnya human capital adalah pengetahuan yang ada pada sumberdaya manusia merupakan 
basis penggerak dalam peningkatan produktivitas.

Human Capital dalam suatu organisasi terdiri dari individu-individu yang bekerja di dalamnya. Human capital jugalah yang menjadi dasar kegiatan organisasi. Universitas Negeri Yogyakarta merupakan sebuah organisasi yang memiliki dan mengelola tenaga kependidikan. Lembaga tersebut mempunyai banyak tenaga kependidikan yang dapat dikembangkan. Alasan mengapa pendidikan sebagai human capital investment bagi tenaga kependidikan yang bekerja di UNY adalah karena pendidikan merupakan investasi yang paling penting dalam modal manusia untuk menjawab tantangan global pada saat ini.

(Fitz-ens, 2000, pp.xii) menyatakan pengertian human capital dapat dijelaskan sebagai suatu kombinasi dari faktor-faktor sebagai berikut: (a) sifat-sifat seseorang yang dibawanya sejak lahir ke dalam pekerjaan, inteligensi, energi, sikap yang secara umum positif, reabilitas, komitmen; (b) Kemampuan seseorang untuk belajar, bakat, imajinasi, kreativitas, dan apa yang sering disebut sebagai street smart (akal kecerdasan); (c) motivasi seseorang untuk berbagi informasi dan pengetahuan, semangat tim dan orientasi tujuan.

Komponen dari investasi pendidikan meliputi Output pendidikan berbentuk perolehan belajar, seperti peningkatan pengetahuan, keterampilan, pemahaman, dan perubahan sikap. Manfaat dalam pendidikan itu diperoleh hanya apabila output belajar digunakan secara efektif di masyarakat. Dengan demikian, manfaat pendidikan itu bukan pada output dari proses pendidikan, melainkan bagaimana output pendidikan itu digunakan. Penggunaan output belajar yang efektif bukan merupakan fungsi dari input biaya pendidikan karena hal tersebut dipengaruhi oleh banyak faktor di luar pendidikan.

(Stockley, 2003, pp.41) menyatakan human capital memiliki pengertian "the term of human capital is recognition that people in organization and business are an important and essential asset who contribute to development and growth, in a similar way as physical asset such as machines and money. The collective attitude, skill and abilities of people contribute to organization performance and productivity. Any expenditure in training, development, health and support is an investment not just an expense".

Sejalan dengan human capital investment tersebut, UNY memberikan kesempatan kepada para tenaga kependidikan untuk melanjutkan sekolah pada jenjang yang lebih tinggi. Jumlah tenaga kependidikan (PNS) yang ada di UNY adalah 536 mulai dari jenjang SD sampai dengan S2. Realita yang ada, jumlah pendidikan tenaga kependidikan lulusan jenjang SMA lebih banyak dibandingkan dengan lulusan jenjang perguruan tinggi (D2/D3/S1/S2).

Terdapat hal yang perlu dianalisa mengapa jumlah tenaga kependidikan jenjang SMA masih banyak. Padahal asumsi dasar teori human capital investment adalah bahwa seseorang dapat meningkatkan penghasilannya melalui peningkatan pendidikan. Setiap tambahan satu tingkat pendidikan berarti disatu pihak meningkatkan kemampuan dalam bekerja dan meningkatkan penghasilannya dan dipihak lain adalah menunda penerimaan penghasilan selama kurun waktu tertentu dalam mengikuti pendidikan tersebut.

Perhatian pimpinan di UNY terhadap SDM atau human capital sebagai salah satu faktor produksi utama bagi kebanyakan organisasi sering dinomorduakan dibandingkan dengan faktor-faktor produksi yang lain seperti teknologi, sarana prasarana, dan uang. Banyak para pemimpin lembaga kurang menyadari bahwa sebenarnya keuntungan yang diperoleh organisasi berasal dari human capital. Hal ini disebabkan karena aktivitas organisasi hanya dilihat dari perspektif bisnis semata. Para pemimpin di UNY tidak melihat SDM sebagai unit pengetahuan dan keterampilan yang unik dan perlu dikembangkan. Bukan hanya SDM dari kalangan tenaga pendidik, namun tenaga kependidikan juga perlu dipertimbangkan.

Tenaga kependidikan yang ada di UNY belum sepenuhnya mengetahui fungsi dari human capital investment. Hal ter- 
sebut dapat diidentifikasi sebagaian dari para tenaga kependidikan yang ada lebih enjoy menikmati pekerjaan yang sudah ada saat ini. Sulit untuk keluar dari zona nyaman dan mengembangkan pengetahuannya. Kebanyakan tenaga kependidikan sudah tidak peduli dengan ilmu yang dimiliki, karena tugas sehari-hari dalam bekerja dapat dilatih secara intens dan tidak memerlukan pendidikan lebih lanjut. Kenaikan pangkat dan jabatan, hanya menunggu masanya tiba.

Tenaga kependidikan yang bekerja di UNY dan melanjutkan pendidikan pada jenjang yang lebih tinggi akan mendapatkan kualitas dalam bekerja yang baik. Hakikat tersebut dapat terlihat pada beberapa tenaga kependidikan yang telah selesai melakukan peningkatan pendidikan, hal itu sejalan dengan teori human capital investment, bahwa pendidikan mempunyai pengaruh terhadap pertumbuhan ekonomi karena pendidikan berperan dalam peningkatan produktivitas dalam bekerja. Semakin tinggi pendidikan formal yang diperoleh seseorang maka akan meningkatkan produktivitas kerja orang tersebut.

Peningkatan mutu human capital investment tidak dapat dilakukan dalam tempo yang singkat, namun memerlukan waktu yang panjang. Human capital investment sebenarnya sama dengan investasi faktor produksi lainnya. Perlu memperhitungkan rate of return (manfaat) dari human capital investment. Tenaga kependidikan di UNY yang akan melakukan investasi, memang sebaiknya melakukan cost benefit analysis (analisa biaya manfaat). Biayanya adalah berupa biaya yang dikeluarkan untuk bersekolah dan opportunity cost dari bersekolah adalah penghasilan yang diterimanya bila tenaga kependidikan tidak bersekolah. Manfaatnya adalah penghasilan (return) yang akan diterima di masa depan setelah masa sekolah selesai.

(Simarmata, 1985, pp.156) menyatakan mengelompokkan analisis investasi secara umum menjadi 2 bagian, yaitu: (1) analisis investasi statis, meliputi: (a) rentabilitas, (b) payback period, (c) B/C ratio, dan (d) return on investment); dan (2) analisis investasi dinamis, meliputi: (a) net present value, (b) internal rate of return, dan (c) profitability index).

Pengukuran human capital investment dan rate of return bagi tenaga kependidikan UNY yang melanjutkan pendidikan belum pernah dilakukan. Bertitik tolak dari hal itu, penting kiranya dilakukan sebuah kegiatan analisa untuk mengetahui pengukuran human capital investment dan rate of return bagi tenaga kependidikan di UNY yang akan melakukan peningkatan pendidikan.

Berdasarkan urainan tesebut, penelitian ini bertujuan untuk menganalisis: (1) payback period (PP), (2) benefit/cost ratio, (3) return on investment (ROI), (4) net present value (NPV), dan (5) internal rate of return (IRR) dalam perspektif pendidikan bagi tenaga kependidikan di Universitas Negeri Yogyakarta.

\section{Metode Penelitian}

Penelitian ini adalah penelitian evaluasi dengan menggunakan pendekatan kuantitatif. Penelitian evaluasi ini dilaksanakan pada bulan September-Desember 2014 di Universitas Negeri Yogyakarta. Subjek dalam penelitian evaluasi ini adalah seluruh tenaga kependidikan yang bekerja di Universitas Negeri Yogyakarta (khususnya yang sudah PNS) berjumlah 536 orang tenaga kependidikan. Sampel untuk validasi berjumlah 30 orang sedangkan sampel penelitian berjumlah 205 (Sampel diperoleh dari Tabel Populasi Issac dan Michael). Prosedur dalam penelitian ini adalah dengan cara membuat kisi-kisi kuesioner, pedoman dokumentasi, dan format wawancara. Setelah data terkumpul selanjutnya dianalisis dengan menggunakan rumus Human Capital Investment dan dengan menggunakan Statistik Deskriptif dengan bantuan Software SPSS versi 21.

Data dikumpulkan dengan menggunakan kuesioner dan wawancara, selanjutnya dianalisis dan disimpulkan dengan menggunakan deskriptif. Teknik analisis data dilakukan dengan dua hal yaitu dengan menggunakan rumus Human Capital 
Investment, meliputi: (1) penghitungan Payback Period bagi tenaga kependidikan yang sedang melangsungkan pendidikan; (2) menghitung Benefit/Cost Ratio; (3) menghitung Return on Investment; (4) menghitung Net Present Value; dan (5) menghitung Internal Rate of Return. Analisis yang kedua untuk mengevaluasi menggunakan soft-ware dengan bantuan SPSS versi 21 dengan analisis statistik deskriptif.

\section{Hasil Penelitian dan Pembahasan}

Hasil penghitungan Payback Period adalah total waktu yang dibutuhkan untuk pengembalian investasi tidak melebihi batas waktu studi yang ditentukan. Hal itu terbukti pada hasil penghitungan dari kedua tenaga kependidikan. Tenaga kependidikan dari jenjang S1 ke jenjang S2 memiliki payback period 1 tahun 7 bulan 9 hari tidak melebihi batas waktu yang ditentukan yaitu selama 4 tahun, sedangkan tenaga kependidikan yang melanjutkan pada jenjang S3 memiliki Payback Period 2 tahun 3 bulan 21 hari dari standar waktu yang ditentukan yaitu 5 tahun. Hasil penghitungan statistik deskriptif dengan menggunakan SPSS versi 21 memiliki skor capaian $83,69 \%$. Angka tersebut menunjukkan bahwa kemampuan tenaga kependidikan yang bekerja di Universitas Negeri Yogyakarta dalam pengembalian investasi pendidikan tidak melebihi batas waktu yang telah ditentukan, sehingga Payback Period investasi dalam pendidikan efektif karena memiliki kesenjangan yang lebih kecil.

Hasil penghitungan Benefit/Cost Ratio adalah uang yang digunakan oleh tenaga kependidikan dalam investasi pendidikan memberikan manfaat positif bagi tenaga kependidikan itu sendiri, hal ini dibuktikan pada hasil penghitungan pada tenaga kependidikan yang melanjutkan jenjang S2 yaitu 1,48\% dan tenaga kependidikan yang melanjutkan jenjang S3 sebesar 1,54\%. Angka tersebut menunjukkan bahwa benefit.cost Ratio dalam pendidikan memberikan ketepatan dalam mendayagunakan anggaran dengan memberikan priortias pada faktor- faktor input dibidang pendidikan tenaga kependidikan yang dapat memacu pencapaian prestasi kerja sehingga memberikan manfaat yang baik bagi tenaga kependidikan tersebut. Hasil penghitungan statistik deskriptif dengan menggunakan SPSS versi 21 menunjukkan 77,56\% dan lebih besar dari nilai kesenjangan. $77,56 \%$ dapat diartikan bahwa kebijakan strategis dalam pengelolaan cost dalam pendidikan oleh tenaga kependidikan yang berprinsip pada keseimbangan antara biaya (cost) pendidikan yang dikeluarkan dengan manfaat (benefit) yang diterima, sehingga $\mathrm{B} / \mathrm{C}$ Ratio dapat efektif.

Hasil penghitungan Return on Investment tenaga kependidikan yang melanjutkan S2 adalah 48\% sedangkan tenaga kependidikan yang melanjutkan S3 sebesar $54 \%$. Persentase tersebut tidak kecil, sehingga ROI bagi tenaga kependidikan yang melakukan peningkatan kualifikasi pendidikan tidak merugikan. Angka presentase yang semakin besar dapat memberikan pengembalian semakin besar pula. ROI yang lebih tinggi akan memberikan keuntungan yang tinggi. Hasil penghitungan statistik deskriptif dengan menggunakan SPSS versi 21 sebesar 77,07\%. Angka tersebut menunjukkan bahwa ROI bagi tenaga kependidikan yang melakukan investasi dalam bidang pendidikan menyetujui bahwa ROI dapat memberikan keuntungan yang baik bagi tenaga kependidikan, sehingga investasi dalam pendidikan bagi tenaga kependidikan dapat diterima, karena memiliki kesenjangan yang lebih sedikit dibanding dengan angka presentase yang dihasilkan.

Hasil penghitungan Net Present Value adalah Positif, hal ini dapat terbukti pada hasil penghitungan tenaga kependidikan yang melanjutkan S2 yaitu sebesar Rp17.059.305,- sedangkan tenaga kependidikan yang melanjutkan S3 sebesar Rp7.027.573,- Estimasi hasil pendidikan secara moneter dengan memperhatikan faktor biaya dan perubahan nilai uang tidak mempengaruhi secara langsung dari investasi pendidikan yang dilakukan. Angka rupiah tersebut menggambarkan bahwa 
pendapatan yang akan diterima oleh tenaga kependidikan pada tahun yang akan datang tidak mengalami penurunan akibat inflasi, maksudnya adalah NPV dalam perspektif pendidikan tersebut memperhitungkan nilai uang yang beruba/berbeda antara masa sekarang dengan masa datang. Hasil penghitungan statistik deskriptif dengan menggunakan SPSS versi 21 diatas rata-rata yaitu sebesar $84,07 \%$. Rata-rata tersebut lebih besar dibanding dengan kesenjangan sehingga NPV dalam inestasi pendidikan layak untuk dilakukan. Angka tersebut menunjukkan bahwa tenaga kependidikan yang bekerja di Universitas Negeri Yogyakarta paham akan hal dalam memperkirakan hasil pendidikan tinggi yang merupakan cara estimasi hasil pendidikan secara moneter dengan memperhatikan faktor biaya dan perubahan nilai uang.

Hasil penghitungan Internal Rate of Return bagi tenaga kependidikan yang sedang melanjutkan pendidikan pada jenjang S2 adalah 20,09\% sedangkan hasil penghitungan IRR bagi tenaga kependidikan yang melanjutkan pada jenjang S3 sebesar 15,72\%. Angka IRR berada di atas cost of capital $(7,50 \%)$, dapat diartikan bahwa tingkat discount yang mempersamakan hasil dari melanjutkan pendidikan tinggi dengan biaya total dapat memberikan pendapatan baik. Hasil penghitungan statistik deskriptif dengan menggunakan SPSS versi 21 diatas rata-rata yaitu 97,07\%. Angka tersebut menunjukkan bahwa tenaga kependidikan yang bekerja di Universitas Negeri Yogyakarta paham dengan metode perhitungan investasi dengan menghitung tingkat bunga yang menyamakan nilai sekarang investasi dengan nilai sekarang dari penerimaan-penerimaan bersih di masa datang. Kesimpulan dari angka tersebut memberikan makna bahwa investasi dalam pendidikan tersebut dapat dinyatakan efektif (feasible)

Hasil penelitian Human Capital Investment dalam Perspektif Pendidikan bagi Tenaga Kependidikan di Universitas Negeri Yogyakarta dapat dilihat pada tabel 2.
Tabel 2. Rekapitulasi Hasil Analisis Statistik Deskriptif dari SPSS Versi 21

\begin{tabular}{|c|c|c|c|}
\hline No & Aspek & $\begin{array}{c}\text { Skor } \\
\text { Capaian } \\
(\%)\end{array}$ & $\begin{array}{c}\text { Kesenjanga1 } \\
(\%)\end{array}$ \\
\hline & Payback Period & 83,69 & 16,31 \\
\hline & B/C Ratio & 77,56 & 22,44 \\
\hline & Return on Investment & 77,07 & 22,93 \\
\hline & Net Present Value & 84,07 & 15,93 \\
\hline & Internal Rate of Return & 97,07 & 2,93 \\
\hline & Jumlah & 419,46 & 80,54 \\
\hline & Rata-rata & 83,892 & 16,108 \\
\hline & Standar Deviasi & 8,07 & 8,07 \\
\hline
\end{tabular}

Rekapitulasi data berdasarkan Tabel 2 tersebut disajikan dalam diagram sebagaimana Gambar 5.

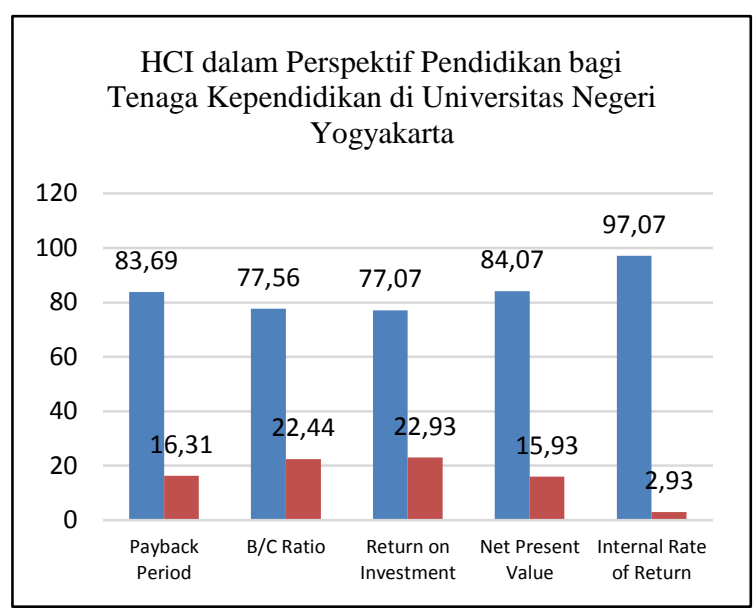

Gambar 4. Rekapitulasi Data dari SPSS

Dari data tersebut terlihat bahwa pelaksanaan peningkatan kualifikasi pendidikan bagi tenaga kependidikan di Universitas Negeri Yogyakarta terdapat tiga aspek yang mendekati standar, ditunjukkan dengan capaian skor di atas rata-rata dapat dilihat pada Tabel 3.

Tabel 3. Aspek Human Capital Investment yang Mendekati Standar

\begin{tabular}{llcc}
\hline No. & \multicolumn{1}{c}{ Aspek } & \multicolumn{2}{c}{$\begin{array}{c}\text { Skor } \\
\text { Capaian }\end{array}$} \\
& & $\begin{array}{c}\text { Kesenjangan } \\
(\%)\end{array}$ \\
\hline 1. & Return on Investment & 77,07 & 22,93 \\
2. & Net Present Value & 84,07 & 15,93 \\
3. & Internal Rate of Return & 97,07 & 2,93 \\
\hline
\end{tabular}


Dua yang lain termasuk aspek dengan capaian di bawah rata-rata dalam pelaksanaan peningkatan kualifikasi pendidikan bagi tenaga kependidikan di Universitas Negeri Yogyakarta. Aspek-aspek tersebut disajikan pada Tabel 4 .

Tabel 4. Aspek Human Capital Investment di Bawah Rata-Rata

\begin{tabular}{|c|c|c|c|}
\hline$\overline{\mathrm{No}}$ & Aspek & $\begin{array}{c}\text { Skor } \\
\text { Capaian } \\
(\%)\end{array}$ & $\begin{array}{c}\text { Kesenjangan } \\
(\%)\end{array}$ \\
\hline 1. & Return on Investment & 77,07 & 22,93 \\
\hline 2. & Net Present Value & 84,07 & 15,93 \\
\hline
\end{tabular}

Berdasarkan lima metode kelayakan pada aspek keuangan yang digunakan dalam menilai investasi dari Human Capital Investment dapat dilihat pada Tabel 5.

Tabel 5. Rekapitulasi Hasil Analisis Kelayakan Investasi

\begin{tabular}{|c|c|c|c|}
\hline $\begin{array}{l}\text { Metode } \\
\text { Penilaian }\end{array}$ & Nilai & $\begin{array}{c}\text { Standar yang } \\
\text { ditetapkan }\end{array}$ & Ket. \\
\hline $\begin{array}{l}\text { Payback Period } \\
(\mathrm{PP})\end{array}$ & $\begin{array}{l}\text { 1. } 1 \text { tahun } 7 \\
\text { bulan } 9 \text { hari } \\
\text { 2. } 2 \text { tahun } 3 \\
\text { bulan } 21 \\
\text { hari }\end{array}$ & $\begin{array}{l}\text { Umur } \\
\text { Ekonomis } \\
4 \text { tahun } \\
5 \text { tahun }\end{array}$ & $\begin{array}{l}\text { UE > PP } \\
\text { Investasi } \\
\text { layak }\end{array}$ \\
\hline B/C Ratio & $\begin{array}{l}\text { 1. } 1.48 \% \\
\text { 2. } 1.54 \%\end{array}$ & B/C Ratio (+) & $\begin{array}{l}\text { B/C Ratio + } \\
\text { Investasi } \\
\text { layak }\end{array}$ \\
\hline $\begin{array}{l}\text { Return on } \\
\text { Investment } \\
(\mathrm{ROI})\end{array}$ & $\begin{array}{l}\text { 1. } 48 \% \\
\text { 2. } 54 \%\end{array}$ & $\mathrm{ROI}(+)$ & $\begin{array}{l}\text { ROI + } \\
\text { Investasi } \\
\text { layak }\end{array}$ \\
\hline $\begin{array}{l}\text { Net Present } \\
\text { Value (NPV) }\end{array}$ & $\begin{array}{l}\text { 1. Rp17.059.305 } \\
\text { 2. Rp7.027.573 }\end{array}$ & $\mathrm{NPV}(+)$ & $\begin{array}{l}\mathrm{NPV}+ \\
\text { Investasi } \\
\text { layak }\end{array}$ \\
\hline $\begin{array}{l}\text { Internal Rate of } \\
\text { Return (IRR) }\end{array}$ & $\begin{array}{l}\text { 1. } 20.09 \% \\
\text { 2. } 15.72 \%\end{array}$ & $\begin{array}{l}\text { WACC: } 13 \% \\
\text { (Weight } \\
\text { Average Cost } \\
\text { of Capital) }\end{array}$ & $\begin{array}{l}\text { IRR + } \\
\text { Investasi } \\
\text { layak }\end{array}$ \\
\hline
\end{tabular}

\section{Simpulan dan Saran}

Simpulan

Tenaga kependidikan dari jenjang S2 memiliki payback period 1 tahun 7 bulan 9 hari tidak melebihi 4 tahun, sedangkan jenjang S3 memiliki Payback Period 2 tahun 3 bulan 21 hari tidak melebihi 5 tahun. Hasil statistik deskriptif memiliki skor ca- paian 83,69\%, sehingga Payback Period investasi dalam pendidikan efektf.

Penghitungan pada tenaga kependidikan yang melanjutkan jenjang S2 yaitu $1,48 \%$ dan jenjang S3 sebesar 1,54\%. Hasil statistik deskriptif 21 menunjukkan 77,56\%, dapat diartikan bahwa terdapat keseimbangan antara biaya (cost) pendidikan yang dikeluarkan dengan manfaat (benefit) yang diterima, sehingga B/C Ratio dapat efektif.

Hasil penghitungan ROI S2 adalah $48 \%$ sedangkan S3 sebesar 54\%. Hasil penghitungan statistik deskriptif dengan sebesar 77,07\%. Angka tersebut menunjukkan bahwa ROI bagi tenaga kependidikan efektif.

Hasil penghitungan Net Present Value tenaga kependidikan yang melanjutkan S2 yaitu sebesar Rp17.059.305,- sedangkan tenaga S3 sebesar Rp7.027.573,-. Hasil penghitungan statistik deskriptif sebesar $84,07 \%$. Angka tersebut menunjukkan positif sehingga investasi dinilai efektif.

Hasil penghitungan Internal Rate of Return jenjang S2 adalah 20,09\% sedangkan jenjang S3 sebesar 15,72\%. Angka IRR berada di atas cost of capital (7,50\%), Hasil penghitungan statistik deskriptif yaitu 97,07\%. Angka tersebut memberikan makna bahwa investasi dalam pendidikan tersebut dapat dinyatakan efektif (feasible)

Saran

Saran ini ditujukan bagi lembaga tempat penelitian dilaksanakan, yaitu Universitas Negeri Yogyakarta. Saran tersebut adalah: (1) perlu adanya program kerja terkait dengan Human Capital Investment sehingga tenaga kependidikan terfasisilitasi oleh lembaga dalam meningkatkan kualifikasi pendidikan pada jenjang yang lebih tinggi; (2) pimpinan organisasi seharusnya memahami human capital karena dengan konsep human capital dapat mengukur kemampuan tenaga kependidikan untuk mengubah data menjadi hasil yang bernilai bagi organisasi; (3) pimpinan organisasi lebih mengenali nilai dan kontribusi tenaga kependidikan yang ada, dengan demikian dapat menjadikan organisasi yang tumbuh dan berkembang pesat. 


\section{Daftar Pustaka}

Badan Kepegawaian Negara. (1999), Undang-undang RI nomor 43, tahun 1999, tentang perubahan atas undangundang nomor 8 tahun 1974 tentang pokok-pokok kepegawaian.

Becker, Gary S. (1975). Human capital: a theoritical approach and empirical analysis with special reference to education. New York: Columbia University Press. pp.334

Department of Information Systems and Operations Management. (2007). No man is an island: social and human capital in it capacity building in the maldives, University of Auckland Business School, Private Bag 92019, Auckland, New Zealand.
Fitz-enz, Jac. (2000), How to measure human resources management-International Edition, McGraw. pp.xxi

Mayo, Andrew. (2000). The role of employee development in the growth of intellectual capital. Personal Review, 29, 521-533.

Simarmata, Dj. A. (1984), Pendekatan sistem dalam analisa proyek investasi. Jakarta: Gramedia

Stockley, Derek, (2003). Consultant home. Tanggal Akses: 2014-September-1, Website:www.derekstockley.com.a u,URL:http:/ / derekstockley.com.a $\underline{\mathrm{u} / \mathrm{a} \text {-human-resources.html }}$

Tim pengembang ilmu pendidikan FIP-UPI (2008). Ilmu dan aplikasi pendidikan bagian 3 pendidikan disiplin ilmu. Bandung: PT Imperial Bhakti Utama. 